\title{
VEHICLE-ROUTING OPTIMIZATION FOR MUNICIPAL SOLID WASTE COLLECTION USING GENETIC ALGORITHM: THE CASE OF SOUTHERN NABLUS CITY
}

\author{
Ramiz ASSAF ${ }^{1}$, Yahya SALEH ${ }^{2}$ \\ ${ }^{1}$ University of Business and Technology, Jeddah, Saudia Arabia \\ ${ }^{2}$ An-Najah National University, Nablus, Palestine
}

\begin{abstract}
Municipalities are responsible for solid waste collectiont for environmental, social and economic purposes. Practices of municipalities should be effective and efficient, with the objectives of reducing the total incurred costs in the solid waste collection network concurrently achieving the highest service level. This study aims at finding the best routes of solid waste collection network in Nablus city-Palestine. More specifically, the study seeks the optimal route that minimizes the total travelled distance by the trucks and hence the resulted costs. The current situation is evaluated and the problem is modelled as a Vehicle Routing Problem (VRP). The VRP is then optimized via a genetic algorithm. Specifically, compared to the current situation, the trucks total travelled distance was reduced by $66 \%$, whereas the collection time was reduced from 7 hours per truck-trip to 2.3 hours. The findings of this study is useful for all municipality policy makers that are responsible for solid waste collection.
\end{abstract}

Keywords: Solid waste collection, Vehicle routing problem, genetic algorithm, integer program

\footnotetext{
${ }^{1}$ Corresponding author: University of Business and Technology, Industrial Engineering Department, Jeddah 21361, Saudia Arabia

${ }^{2}$ Corresponding author: An-Najah National University, Industrial Engineering Department, P.O.Box 7, Nablus, Palestine
} 


\section{INTRODUCTION}

From users' perspective, solid wastes (SW) generated as a result of different human activities are technically referred to all non-valuable materials to be maintained for future usage. More specifically, such materials consist of biodegradable wastes commonly found in municipal solid wastes (MSW), green wastes, plastic and paper wastes, food wastes, glass wastes and textile wastes generated from daily residential, commercial and industrial human activities. The generated amounts of SWs in any region are proportional to the population growth as well as to the commercial and industrial activities. The global community agrees on the adverse impacts of SWs on environment, natural resources (e.g. groundwater) and human health if not being treated effectively, thus an effective and efficient SWs management system is inevitable by local authorities (municipalities), (Vecchi et al., 2016).

SWs management problem in cities is a multi-faceted problem composed of many stages including generation, collection, treatment (processing) and disposal. From the viewpoints of users and decision-makers in municipalities, the collection stage of SWs receives a relatively greater attention to be seriously and carefully taken into consideration as the ignorance of such stage results in harmful impacts. Namely, as mentioned by Detofeno and Steiner (2010), SWs collection approximately costs $50 \%$ of the public sanitation system. Besides, the trucks picking up and carrying the collected SWs are considered to be very notorious in gas emissions to atmosphere where they emit about $1.24 \mathrm{Kg}_{\text {of }} \mathrm{CO}_{2}$ per travelled kilometer $(\mathrm{Km})$. In the sequel, an effective routing problem of the SWs collection trucks is extremely important to be addressed. The trucks routing problem has been addressed by many researchers and is well-known in optimization literature as a vehicle-routing problem (VRP). As defined in Dror (2001), VRP mainly deals with the optimization problem aiming at identifying the efficient and optimal (with minimal travelled distance or cost) routes of vehicles (trucks) assigned for picking up and collecting goods using a fleet of a set of trucks (identical or non-identical) serving a set of customers with known demand.

In the context of MSWs, several papers in the literature have dealt with SWs management and optimization in many case studies in many countries around the world. To name but a few, Tavares et al. (2008) in Cape Verde, Huang et al. (2011) in Taiwan, Bonomo et al. (2012) in Argentina, Rada et al. (2013) in China and Malaysia, Yao et al. (2013) in China, Mes et al. (2014) in the Netherlands, Gallardo et al. (2015) in Spain, Ravindra et al. (2015) in India and Garrido and Bronfman (2016) in Chile.

On the other hand, many works have been conducted on optimizing the MSWs collection problems through modeling them as a VRP under different specific 
settings in different countries and solving them using well-known optimization methods. Kim et al. (2006) addresses a real life waste collection VRP in North America with time windows considering multiple disposal trips and drivers' lunch breaks. $\mathrm{Li}$ et al. (2008) addressed a truck scheduling problem in the context of solid waste collection in Brazil. Another study by Aguiar et al. (2012) modelled and solved a Periodic VRP with the additional constraint that routes must pass through one of the alternative disposal facilities before returning to the depot. Buhrkal et al. (2012) studied the waste collection VRP with time window for the purpose of finding the optimal routes of garbage trucks in a Danish SW collection company. Similar to this work, Moon et al. (2012) modelled and solved a VRP with time windows considering overtime and outsourcing vehicles for a third-party applied to real cases in South Korea. A study by Hemmelmayr et al. (2013) considered a real world VRP for SW (glass, metal, plastics and paper) collection in Austria. Choy et al. (2014) presented an extensive state-of -the-art literature review of green VRPs classified into green-VRPs, pollution routing problems and VRP in reverse logistics. Also, Yu and Solvang (2015) summarized in a state-of-the-art the literature pertinent to the methodologies and contemporary researches for VRP in MSWs. Another literature survey study was conducted by Han and Cueto (2015) summarizing the major contribution of VRP in MSWs collection considering residential, commercial and industrial waste management systems. Koc et al. (2016) classified and reviewed a thirty years literature on heterogeneous VRPs as well as the metaheuristics employed in solving them. Also, Li et al. (2016) presented an extensive survey on three primary types of combination truck routing problems (CTRP), specifically, truck and trailer routing problem, the roll on-roll off VRP and the tractor and semitrailer routing problem. Other studies related to the VRP of SW collection include Toro et al. (2016), Paul et al. (2016), Prodhon and Prins (2014), Xie et al. (2013), Riesabadi and Mirmohammadi (2015), Huang and Lin (2015) and Bing et al. (2016).

This study addresses the MSW collection optimization problem in the southern region of Nablus city which is in the West Bank of Palestine. More specifically, the problem is modeled as a VRP with goal of finding the optimal routes that minimize the total distance travelled by Nablus municipality's vehicles (trucks) and hence that minimize the corresponding total incurred costs.

The remainder of the paper is structured as follows. Section two presents the research problem statement and the considered case study (Nablus city). In section three, the preliminaries and the specifics of the vehicle-routing optimization model are given. Section four includes the optimal solution of the modelled VRP using genetic algorithm. The discussion of the obtained results as 
well as the sensitivity analysis are presented in section five. Section six concludes our work.

\section{PROBLEM STATEMENT}

In this study we consider the optimization VRP of MSWs collection problem in Nablus city located in the northern West Bank in Palestine, approximately 49 $\mathrm{Km}$ north of Jerusalem. Nablus has one of the oldest municipalities in Palestine where its establishment dated back to 1869. In addition to other services, the municipality provides MSWs collection service to all regions in the city with a total area of $605 \mathrm{Km} 2$ and 351,400 persons including the old city, villages and three refugee camps. The daily amount of solid wastes (residential, commercial and industrial) collected in all regions in Nablus is about 300 tons. Furthermore, in order to increase the quality of provided SW collection service; the municipality divides Nablus city into two regions: southern and northern region, (http://nablus.org/index.php/en/about-municipality/about-municipality).

More specifically, the municipality outsources the southern region to a semigovernmental entity called the Common Service Council (CSC), whereas the solid waste collection division of Nablus municipality keeps managing and collecting SW from the northern region. The scope of this work is limited only to the southern region of Nablus city shown in the upper non-shaded part of the map figure (1), as the CSC has already collected GIS information for the southern region's dumpsters' locations on the map of the city. Unfortunately, no such reliable GIS information are available for the northern region of the city, thus, the northern region of the city is out of the scope of this study. To exploit the GIS information available for the southern region of the city, the municipal council was very interested to augment the GIS information in a model that results in a better performance for the MSW collection network in the southern region of the city. Specifically, a model that minimizes the total travelled distance and collection costs while improving the quality of collection service. This was the core motivation behind doing this research.

The current system for SWs collection in the southern region of Nablus is merely based on experience of truck drivers, which led to high operational costs, repeated visits to some dumpsters while some are skipped. The general objective of this work is to develop a mathematical model that minimizes the total distance traveled by the MSW collection trucks. Due to the large number of dumpsters in the southern region of the city the researchers utilized GA to arrive to the near-optimal solution of the model. To this end, the SW collection problem in the southern region of the city was formulated and analyzed a mathematical model for a capacitated vehicle routing problem (CVRP). Then, 
using GA, the shortest route for each vehicle (truck) was identified; such shortest routes guarantee visiting all dumpsters only once in each trip.

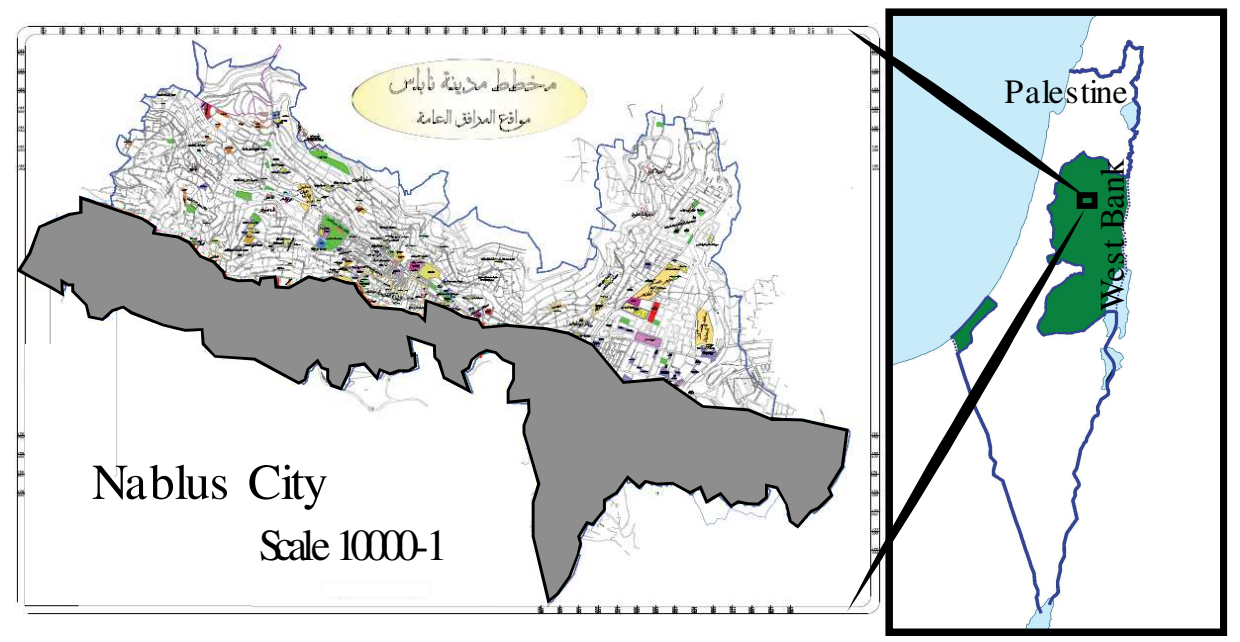

Fig. 1. The Scope of the work within the city of Nablus in the West Bank of Palestine

The findings of this work are expected to have positive impacts on the administration of Nablus municipality, inhabitants of the city as well as the environmental reality in the city. Specifically, the impact on the municipality's administration appears in the form of reducing collection time and operational cost (fuel, maintenance of trucks and labor). This will also affect the inhabitants of the city as the service is improved and overall it reduced fuel consumption and thus emissions coupled with fast and on-time pickups of solid waste that will benefit the environmental reality in the city and the quality of life of its inhabitants. Our work fits within the literature of other previous works on MSWs collection problems in other developing countries. To name but a few, Amponsah and Salhi (2004) investigated in a literature review the classes of capacitated VRP in developing countries. El-Hamouz (2008) investigated the MSWs management system of Tubas municipality to the north of Nablus city to reduce the MSWs collection costs via private sector involvement. Forouhar and Hristovski (2012) characterized the MSW system in Afghanistan. Lohri et al. (2014) in Ethiopia, Bolaane and Isaac (2015) in Bostwana, Kinobe et al. (2015) in Uganda, Vidovic et al. (2016) in Serbia, Abdelli et al. (2016) in Algeria, Alshraideh and Qdais (2016) in Jordan and Shirazi et al. (2016) in Iran. 


\section{OPTIMIZATION MODEL OF THE VEHICLE ROUTING PROBLEM}

The problem on hand can be analysed as a directed strongly connected and complete graph $\mathrm{G}=(V, A)$ with a set of vertices $V$ and a set of arcs $A$ connecting those vertices. The locations of dumpsters that are to be visited by a fleet of vehicles (trucks) are represented by the set $V$, where $\mathrm{V}=\{0,1,2, \ldots, n$, $L$ \}, where 0 denotes the depot from which each vehicle starts and returns after finishing its route and L stands for the landfill; the place at which each vehicle disposes its load of solid wastes before returning to the depot. Define the set $V^{\prime}=V \backslash\{0, L\}$ is the set of $n$ dumpsters to be visited where each dumpster has a demand (solid waste quantity) of $d_{i}$. The set of arc $A$ is defined by $A=\{(i, j): i, j \in V\}$. Also, let $K=1, \ldots, k$ be the set of identical vehicles (trucks), each with capacity $Q \geq d_{i}, \forall i \in V^{\prime}$. Define $C$ as the matrix of nonnegative distances, $c_{i j}$ between dumpster $i$ and dumpster $j$ (i.e. shortest path or Euclidean distance such that $c_{i l}+c_{l j} \geq c_{i j}, \forall i, j \in V$ ), with $c_{i i}=\infty, \forall i \in V$. Now, we define $x_{i j k}$ as 1 if a truck $k$ goes from dumpster $i$ to directly to dumpster $j$ and zero otherwise. The corresponding optimization model of this VRP could be given as follows. The objective function of the VRP is to minimize the total distances travelled by all trucks.

$$
\begin{array}{cc}
\min . \sum_{k \in K} \sum_{i \in V} \sum_{j \in V} c_{i j} x_{i j k} & \\
\sum_{k \in K} \sum_{i \in V} x_{i j k}=1 & \forall j \in V^{\prime} \\
\sum_{k \in K} \sum_{j \in V} x_{i j k}=1 & \forall i \in V^{\prime} \\
x_{L 0 k}=1 & \forall k \in K \\
x_{0 L k}=0 & \forall k \in K \\
u_{i}-u_{j}+Q x_{i j k} \leq Q-d_{j}, & \forall i, j \in V^{\prime}, i \neq j, k \in K
\end{array}
$$




$$
\begin{array}{cc}
d_{i}+d_{j} \leq Q, & \forall i, j \in V^{\prime}, i \neq j \\
d_{i} \leq u_{i} \leq Q, & \forall i, j \in V^{\prime} \\
x_{i j k} \in\{0,1\} & \forall i, j \in V, k \in K \\
u_{i} \in \mathfrak{R}_{+} & \forall i \in V^{\prime}
\end{array}
$$

Equation (3.1) is the objective function of the VRP which calculates the minimum sum of the total travelled distances by all municipal vehicles (trucks). The constraints in equations (3.2) and (3.3), respectively, guarantee that each dumpster's location is entered by one truck only once and it is left after being served by that truck. The constraint in equation (3.4) states that all trucks should leave the landfill location $(L)$ and return back immediately to the depot $(0)$. The constraint in equation (3.5) confirms that no empty truck would go from depot to the landfill directly before visiting dumpsters. Equation (3.6) guarantees that the routes must be connected (no sub-routes) while equations (3.7) and (3.8) guarantee that the demand on each route should not exceed the truck's capacity. Equations (3.9) and (3.10), respectively, are the integrality and positivity and continuity of the model's decision variables.

Solid wastes in the southern region of Nablus are collected by the municipality's trucks in the time window from 19:00 to 1:00 am. Thus the model does not assume any constraints on the collection time windows. The model assumes constant truck speed, $67 \%$ fill rate of each dumpster, the time requires to empty each dumpster is fixed. In addition, the case assumes a fixed number of trucks available for the CSC to use. Specifically, the total number of trucks available are two trucks, each required to do two trips during collection. In other words, this could be modeled as having four trucks each required to do one trip. The number of dumpsters in the southern region of Nablus is 1230.

\section{GENETIC ALGORITHM}

Since the problem on hand is rather hard to solve using exact integer programming techniques, we chose to apply one of the well-known metaheuristics algorithms; a Genetic Algorithm (GA). This type of algorithm was extensively used to solve such problems, some examples can be found in the recent review work of (Karakatic and Podgorelec, 2015). The solutions (routes) are considered to be near optimal, and by far better than the current approach in SW collection which merely depends on truck drivers' judgment in selecting 
their routes. Briefly, the process of GA can be summarized as follows: The algorithm generates a population of candidate of $n$ chromosomes. Then, is the fitness of each chromosome is evaluated. Finally, reproduction of a new population after applying selection method among new chromosomes, crossover between two chromosomes, and mutation in which changes (with a probability) the structure of the chromosome. This is repeated until certain criterion is met, specifically, to maximize the fitness of the solutions. (Karadimas et al., 2007). To apply the GA correctly, the following parameters of the algorithm should be selected: number of iterations, population, children per generation, mutation policy and probability and selection method. Mutation policy selected in this research was the uniform method that replaces a gene of the chromosome with another value from a user-specified range. Whereas the selection method used was the tournament selection method; which creates randomly small groups of the chromosomes (tournaments) in which they compete to be selected. This would also preserve diversity but would also affect the convergence speed of the algorithm. Based on some initial trials and on the work of Rexhepi et.al. (2013), the population size was set to 1000 . Number of children per generation were set to 500 , Crossover rate and mutations probability were 0.5 and 0.03 , respectively. Finally the tournament size was set to 30 . We applied a nearest neighbor algorithm (NNA) to get a good starting point for the GA to build on. Initial trials indicated that this step would save a lot of computational time, reducing the number of iterations needed to get a solution, as the NNA for VRP takes very short time even for large scale problems. After this step the GA was applied with the provided parameters, the algorithm would stop if it converges to a solution, or if the time limit for the algorithm was exceeded (usually 10 minutes).

\section{RESULTS}

\subsection{Data Collection}

To determine the optimal solution for the VRP stated in equations (3.1)-(3.10), the GIS information should be collected including the coordinates of the depot, landfill, and the dumpsters. Some of the data were previously collected by the $\mathrm{CSC}$, and the missing data were collected using an application on a smartphone that gave the coordinates of the remaining dumpsters. The collected data was then processed to create a distance matrix that indicates the distance between each two nodes in the map. It should be noticed that the distances are driving distances that were obtained from ArcGIS software (https://www.arcgis.com). 


\subsection{Actual Collection Times}

Before using the proposed model to optimize the MSW collection process, data related to the actual collection practices were collected. Table 1 shows the total daily travelled distance (in kilometers, $\mathrm{Km}$ ) gathered from different weeks of work (per truck) covering the period from March-June 2016. It can be noticed there is no fixed schedule per truck, fluctuations are expected as the filling ratio of the dumpsters is also random. Intuitively, the higher the filling ratio, the more trips the trucks need to go to the landfill for SW disposal. It should be emphasized that each truck makes two trips. The CSC were asked about the high variability in their travelled distance, their justification was due to the unfixed truck routing, some locations (dumpsters) are skipped for the following day (sometimes this is done by mistake), which eventually left some dumpsters overfilled. Having some dumpsters overfilled creates an environmental problem represented by the bad smelling of the SWs, some SW bags are left behind the dumpster attracting animals and insects and overall disgusting scene in the left dumpster's neighborhood. Since the landfill is located outside the residential areas of the southern region of the city, frequent going to the land fill results increases the collection time and costs, besides, possible overfilling of some dumpsters.

Table 1. Some actual data about the collection trucks travelling distances $(\mathrm{Km})$

\begin{tabular}{|l|c|c|c|}
\hline \multirow{2}{*}{ Date } & \multicolumn{3}{|c|}{ Travelled distance (Km) } \\
\cline { 2 - 4 } & Truck 1 & Truck 2 & Both Trucks \\
\hline $1 / 3 / 2016$ & 88 & 161 & 249 \\
\hline $10 / 3 / 2016$ & 175 & 154 & 329 \\
\hline $8 / 4 / 2016$ & 174 & 106 & 280 \\
\hline $21 / 4 / 2016$ & 244 & 125 & 369 \\
\hline $3 / 5 / 2016$ & 201 & 112 & 313 \\
\hline $15 / 5 / 2016$ & 214 & 118 & 332 \\
\hline $6 / 6 / 2016$ & 177 & 138 & 315 \\
\hline Average travelled distance $(\mathrm{Km})$ & 182 & 131 & 312 \\
\hline
\end{tabular}

\subsection{Genetic Algorithm Results}

After running the GA algorithm, Table 2 shows the travelling distance per truck, as well as the total distance for affixed assumed filling ratio of $65 \%$. The results in Table 2 seems a bit shocking, as the actual distances that should be travelled is about $1 / 3$ of the current value. The researchers presented the plans to the head of the SWC division at the CSC, the optimal routes were validated to be 
considered a realistic solution. An example, a portion of the proposed solution is depicted in figure 2, where it shows the location of the dumpsters as dots and the route to select as lines.

Based on these results, assuming that the price of 1 liter of diesel fuel is 1.7 $\$ /$ liter. Also assuming that $1 \mathrm{Km}$ needs on average 0.74 liter of fuel. The total operational cost of SW collection with the current implemented solution (for the data shown in Table 1) would be about $\$ 392.5$ per day, or about $\$ 143,262.5$ per year, however, implementing the proposed solution obtained from the GA, the corresponding cost figures would be $\$ 131.8$ per day or $\$ 48,107$ per year. We reasonably assume that SW collection is done every day around the year. Furthermore, travelling less distances, as obtained by the GA, would reduce the working hours of truck drivers and their SW collection staff and the maintenance costs of the trucks would dramatically reduce due to less travelling as well.

Table 2. Optimal travelling distances $(\mathrm{Km})$ by trucks as obtained by the GA with $67 \%$ filling rate

\begin{tabular}{|l|c|c|c|}
\hline & Truck 1 & Truck 2 & Both Trucks \\
\hline Travelled distance (Km) & 45.60 & 59.14 & 104.74 \\
\hline Time to solve (minutes) & \multicolumn{3}{|c|}{9.71} \\
\hline
\end{tabular}

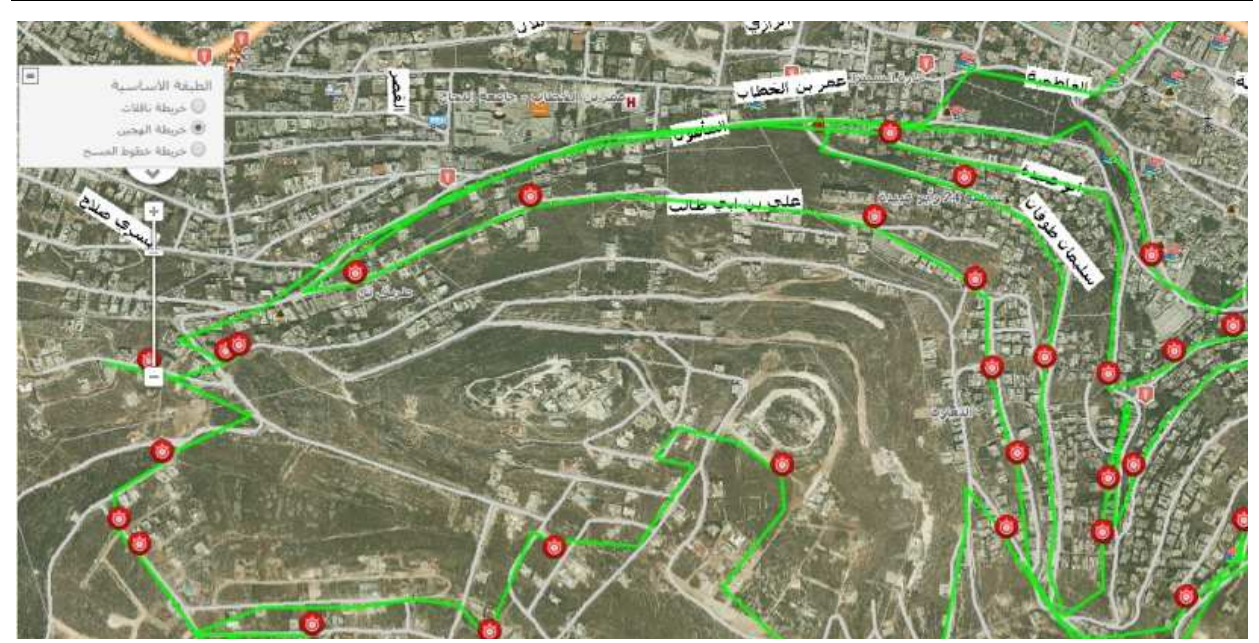

Fig. 2. Portion of the optimal solution of the GA, where the red spots represent dumpsters

Regarding time saving in SW collection, from the collected truck GPS data, each truck moves an average of $45 \mathrm{Km} /$ hour, then the saving in the driving time would be about 4.6 hours per truck. That is about 2 hours 19 minutes per truck 
tour. The processing time (emptying) at each dumpster is the same, so there is not difference between the current situation and the solution obtained by GA.

\subsection{Sensitivity Analysis}

The optimal routes were found based on the assumption that the filling ratio is $67 \%$. Although this assumption is valid, were interested in studying the effect of an increased filling ratio. Table 3 shows the optimal travel distance $(\mathrm{Km})$ when the filling ratio goes up to $80 \%$. The table shows that the distance is increased by around $40 \mathrm{~km}$. This is still much better than the actual travelled route shown in Table 1.

Table 3. Optimal travelling distances $(\mathrm{Km})$ by trucks as obtained by the GA with $67 \%$ filling rate

\begin{tabular}{|c|c|c|c|}
\hline & Truck 1 & Truck 2 & Both Trucks \\
\hline Travelled distance $(\mathrm{Km})$ & 77.20 & 102.75 & 146.6 \\
\hline Time to solve (minutes) & \multicolumn{3}{|c|}{9.31} \\
\hline
\end{tabular}

\section{CONCLUSIONS}

The work presented a case study in which a well-known environmental problem Solid Waste Collection- was optimized using VRP meta-heuristic solution applying GA. The case was for SW collection the southern region of Nablus city in West Bank in Palestine, managed by Nablus municipality. Compared to the current situation, saving in terms of dollar value and time were very significant. This shows the importance of adopting such methodologies in dealing with common municipal SW collection problems. The authors recommend that this approach should be used in other cities in Palestine. Although the solution found is a static solution which cannot be used if some unexpected scenarios happens (such as a truck out of service, or a truck driver is absent) the methodology can be used with acceptable time to find near optimal solutions. The authors suggest that there should be a separate division in the municipality responsible for running and optimizing SW collection problem based on everyday collected data.

\section{REFERENCES}

1. Abdelli, I., Abdelmalek, F., Djelloul, A., Mesghouni, K., Addou, A.: GISbased approach for optimized collection of household waste in Mostaganem city (Western Algeria). Waste Management \& Research, 2016, 34 (5), 417 426. 
2. Aguiar, T., Carravilla, A., Oliveira, J.: Municipal waste collection in Ponte de Lima, Portugal - A vehicle routing application. OR Insights, 2011, 25 (4), 185-198.

3. Alshraideh, H., Abu Qdais, H.: Stochastic modeling and optimization of medical waste collection in Northern Jordan. Journal of Material Cycles and Waste Management, 2016, 1-11.

4. Amponsah, S., Salhi, S.: The investigation of a class of capacitated arc routing problems: the collection of garbage in developing countries. Waste Management, 2004, 24, 711-721.

5. Bing, X., Keizer, M., Ruwaard, J., Vorst, J.: Vehicle routing for the ecoefficient collection of household plastic waste. Waste Management, 2014, 34, 719-729.

6. Bolaane, B., Isaac, E.: Privatization of solid waste collection services: Lessons from Gaborone. Waste Management 2015, 40,14-21.

7. Bonomo, F., Duran G., Larumbe, F., Marenco, J.: A method for optimizing waste collection using mathematical programming: a Buenos Aires case study. Waste Management \& Research, 2012, 30 (3), 311-324.

8. Buhrkal, K., Larsen, A., Ropke, S.: The waste collection vehicle routing problem with time windows in a city logistics context. Procedia - Social and Behavioral Sciences, 2012, 39, 241-254.

9. Detofeno, T., Steiner, M.: Optimizing routes for the collection of urban solid waste: a case study for the City of Joinville, State of Santa Catarina. Iberoamerican Journal of Industrial Engineering, 2010, 2, 124-136.

10. Dror, M., Arc Routing: Theory, Solutions and Applications, 1st ed. Kluwer Academic Press, 2001.

11. El-Hamouz, A.: Logistical management and private sector involvement in reducing the cost of municipal solid waste collection service in the Tubas are, 2008.

12. Eliana, M., Toro, O., Antonio, H., Escobar, Z., Mauricio, E.: Literature review on the vehicle routing problem in the green transportation context. Revista Luna Azul, 2016, 42, 362-387.

13. Forouhar, A., Hristovski, K.: Characterization of the municipal solid waste stream in Kabul, Afghanistan. Habitat International, 2012, 36, 406-413.

14. Gallardo, A., Carlos, M., Peris, M., Colomer, F.: Methodology to design a municipal solid waste pre-collection system. A case study. Waste Management, 2015, 36, 1-11.

15. Garrido, R., Bronfman, A.: Equity and social acceptability in multiple hazardous materials routing through urban areas. Transportation Research Part A, In press, 2016.

16. Han, H., Cueto, E.: Waste Collection Vehicle Routing Problem: Literature Review. Traffic Engineering Review, 2015, 27 (4), 345-358. 
17. Hemmelmayr, V., Doerner, K., Hartl, R., Rath, S.: A heuristic solution method for node routing based solid waste collection problems. Journal of Heuristics, 2013, 19, 129-156.

18. Huang, S., Lin, P.: Vehicle routing-scheduling for municipal waste collection system under the "Keep Trash off the Ground" policy. Omega, 2015, 55, 24-37.

19. Huang, Y., Pan, T., Kao, J.: Performance assessment for municipal solid waste collection in Taiwan. Journal of Environmental Management, 2011, 92, 1277-1283.

20. Karadimas, N., Papatzelou, K., Loumos Vassili, G.: Optimal solid waste collection routes identified by the ant colony system algorithm. Waste Management and Research, 2007, 25 (2), 139-147.

21. Karakatic, S. and Podgorelec, V.: A survey of genetic algorithms for solving multi depot vehicle routing problem. Applied Soft Computing, (2015), 27(0):519- 532 .

22. Kim, B., Kim, S., Sahoo, S.: Waste collection vehicle routing problem with time windows, Computers and Operations Research, 2006, 33, 3624-3642.

23. Kinobe, J., Bosona, T., Gebresenbet, G., Niwagaba, C., Vinneras, B.: Optimization of waste collection and disposal in Kampala city. Habitat International, 2015,49, 126-137.

24. Koc, C., Bektas, T., Jabali, O., Laporte, G.: Thirty years of heterogeneous vehicle routing. European Journal of Operational Research, 2016, 249, $1-21$.

25. Li, H., Lv, T., Lu, Y.: The combination truck routing problem: a survey. Procedia Engineering, 2016, 137, $639-648$.

26. Li, J., Borenstein, D., Mirchandania, P.: Truck scheduling for solidwaste collection in the City of Porto Alegre, Brazil. Omega, 2008, 36, 1133-1149.

27. Lin, C., Choy, K., Ho, G., Chung, S., Lam, H.: Survey of Green Vehicle Routing Problem: Past and future trends. Expert Systems with Applications. 2014, 41, 1118-1138.

28. Lohri, C., Camenzind, E., Zurbrugg, C.: Financial sustainability in municipal solid waste management - Costs and revenues in Bahir Dar, Ethiopia. Waste Management, 2014, 34, 542-552.

29. Mes, M., Schutten, M., Rivera, A.: Inventory routing for dynamic waste collection. Waste Management, 2014, 34, 1564-1576.

30. Moon, I., Lee, J., Seong, J.: Vehicle routing problem with time windows considering overtime and outsourcing vehicles. Expert Systems with Applications, 2012, 39, 13202-13213.

31. of the West Bank. Waste Management, 28, 260-271. 
32. Paul, K., Dutta, A., Krishna A.: A comprehensive study on solid waste vehicle routing and tracking - a case study on Kolkata city. KSCE Journal of Civil Engineering, 2016, 20 (1), 137-144.

33. Prodhon, C., Prins, C.: A survey of recent research on location-routing problems. European Journal of Operational Research, 2014, 238, 1-17.

34. Rada, E., Ragazzi, M., Fedrizzi, P.: Web-GIS oriented systems viability for municipal solid waste selective collection optimization in developed and transient economies. Waste Management, 2013, 33, 785-792.

35. Ravindra, K., Kaur, K., Mor, S.: System analysis of municipal solid waste management in Chandigarh and minimization practices for cleaner emissions. Journal of Cleaner Production, 2015, 93, 251-256.

36. Reisabadi, E., Mirmohammadi, S.: Site dependent vehicle routing problem with soft time window: Modeling and solution approach. Computers \& Industrial Engineering, 2015, 90, 177-185.

37. Rexhepi, A., Maxhuni, A., Dika, A.: Analysis of the impact of parameters values on the Genetic Algorithm for TSP. International Journal of Computer Science, 2013, Vol. 10, Issue 3, No. 1, 158-164.

38. Shirazi, M., Samieifard, R., Abduli, M., Omidvar, B.: Mathematical modeling in municipal solid waste management: case study of Tehran. Journal of Environmental Health Science \& Engineering, 2016, 14 (8), 1-12.

39. Tavares, G., Zsigraiova, Z., Semiao, V., Carvalho, M.: A case study of fuel savings through optimization of MSW transportation routes. Management of Environmental Quality: International Journal, 2008, 19 (4), 444-454.

40. Vecchi, T., Surco, D., Constantion, A., Steiner, M., Jorge, L., Ravagnani, M., Paraiso, P.: A sequential approach for the optimization of truck routes for solid waste collection. Process Safety and Environmental Protection, 2016, 102, 238-250.

41. Vidovic, M., Ratkovic, B., Bjelic, N., Popovic, D.: A two-echelon locationrouting model for designing recycling logistics networks with profit: MILP and heuristic approach. Expert Systems with Applications, 2016, 51, 34-48.

42. Xie, B., Li, Y., Jin, L.: Vehicle routing optimization for deicing salt spreading in winter highway maintenance. Procedia - Social and Behavioral Sciences, 2013, 96, 945 - 953.

43. Yao, L., He, W., Li, G., Huang, J.: The integrated design and optimization of a WEEE collection network in Shanghai, China. Waste Management \& Research, 2013, 31 (9), 910-919.

44. Yu, H., Slovang, W.: Route planning of municipal solid waste management: a methodology and literature review. International Journal of Energy, Environment and Economics, 2015, 23 (1), 1-23. 
VEHICLE-ROUTING OPTIMIZATION FOR MUNICIPAL SOLID WASTE COLLECTION 57 USING GENETIC ALGORITHM: THE CASE OF SOUTHERN NABLUS CITY

\author{
OPTYMALIZACJA ZBIÓRKI ODPADÓW KOMUNALNYCH \\ Z WYKORZYSTANIEM ALGORYTMU GENETYCZNEGO: \\ STUDIUM PRZYPADKU - MIASTO NABLUS PALESTYNA
}

\title{
Streszczenie
}

Gminy są odpowiedzialne za zbiórkę i gromadzenie odpadów stałych z powodów środowiskowych, społecznych i gospodarczych. Działania te powinny być efektywne i skuteczne. Celem jest zmniejszenie poniesionych kosztów na zbiórkę i transport odpadów stałych przy jednoczesnym osiągnięciu najwyższego poziomu usług. $\mathrm{W}$ artykule poddano analizie metody zbierania odpadów stałych w mieście NablusPalestyna. Wyznaczono optymalną trasę, która minimalizuje całkowitą odległość pokonywaną przez ciężarówki, a tym samym koszty. W praktyce sytuacja jest analizowana na bieżąco i modelowana w VRP (Vehicle routing problem). Następnie VRP jest optymalizowany za pomocą algorytmu genetycznego. W porównaniu z obecną sytuacją, całkowite odległości pojazdów w wyniku analizy zostały zmniejszone o $66 \%$, a czas zbierania odpadów komunalnych został skrócony z 7 do 2,3 godziny. Wyniki tego badania są przydatne dla wszystkich decydentów odpowiedzialnych za gromadzenie odpadów stałych.

Słowa kluczowe: zbieranie odpadów, Vehicle routing problem, algorytm genetyczny

Editor received the manuscript: 20.05.2017 